\title{
Not All Rubrics Are Equal: A Review of Rubrics for Evaluating the Quality of Open Educational Resources
}
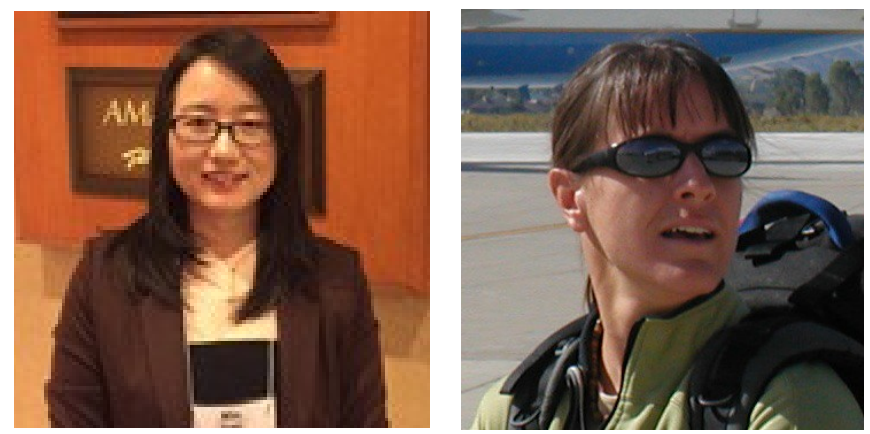

Min Yuan, and Mimi Recker Utah State University, USA

\begin{abstract}
The rapid growth in Internet technologies has led to a proliferation in the number of Open Educational Resources (OER), making the evaluation of OER quality a pressing need. In response, a number of rubrics have been developed to help guide the evaluation of OER quality; these, however, have had little accompanying evaluation of their utility or usability. This article presents a systematic review of 14 existing quality rubrics developed for OER evaluation. These quality rubrics are described and compared in terms of content, development processes, and application contexts, as well as, the kind of support they provide for users. Results from this research reveal a great diversity between these rubrics, providing users with a wide variety of options. Moreover, the widespread lack of rating scales, scoring guides, empirical testing, and iterative revisions for many of these rubrics raises reliability and validity concerns. Finally, rubrics implement varying amounts of user support, affecting their overall usability and educational utility.
\end{abstract}

Keyword: Rubrics, Quality, Open Educational Resources, Content, Development Process, Application Context, Support 


\section{Introduction}

Open Educational Resources (OER) are online teaching, learning, and research resources that can be freely accessed, adapted, used, and shared to support education (U.S. DoE, 2010). Fueled in part by the rapid growth in Internet technologies, a broad range of OER has become widely availability, providing a content infrastructure with the potential for greatly enhancing teaching and learning (Atkins, Brown, \& Hammond, 2007; Borgman et al., 2008; Porcello \& Hsi, 2013). For example, OER can support teachers in gaining and sharing content and pedagogical knowledge, and can provide learners access to a wide variety of resources for extending their knowledge and skills (Haughey \& Muirhead, 2005; Kay \& Knaack, 2007; Khanna \& Basak, 2013). In addition, OER can radically change the way information is presented and the way learners engage with information. Some OER contain images, videos, or interactive content, for instance, helping to make abstract concepts more concrete, while other OER can be adapted to fit learners' different needs (Kay \& Knaack, 2007).

Nonetheless, the wide availability of OER does not assure their high quality or educational utility (Porcello \& Hsi, 2013; Rodríguez, Dodero, \& Alonso, 2011), as both high-quality and low-quality OER can be found throughout the Internet (Bundsgaard \& Hansen, 2011; Fitzgerald, Lovin, \& Branch, 2003). Moreover, low-quality OER can hamper instructional practices and waste teachers' limited time (Abramovich, Schunn, \& Correnti, 2013; Wetzler et al., 2013). As a result, evaluating the quality and appropriateness of OER has become a pressing need (Porcello \& Hsi, 2013).

In response, several researchers and educational organizations have been developing rubrics to help guide the judgment of OER quality. As described below, these rubrics vary widely along a number of critical dimensions. For example, the Learning Object Review Instrument (LORI) from Nesbit, Belfer, and Leacock (2007) is designed to evaluate a wide variety of OER, while the Learning Object Evaluation Instrument (LOEI) from Haughey and Muirhead (2005) is designed for school contexts. The Educators Evaluating the Quality of Instructional Products (EQuIP) from Achieve (2014) focuses on the alignment of OER with educational standards, while the rubric from Fitzgerald and Byers (2002) is targeted at inquirybased science resources. As a final example, the Achieve organization, which developed the rubric for Evaluating Open Education Resource Objects (OER rubric) in 2011 and the EQuIP rubric in 2014, provides extensive training materials for users of these two rubrics, while developers of some other rubrics do not.

In sum, different rubrics possess different characteristics and emphasize different aspects, which can lead to confusion when deciding which rubric to use for OER evaluation. Therefore, in an attempt to synthesize the state of the field, this article provides a review of existing quality rubrics for OER evaluation, and compares them along key characteristics and the kinds of support provided to users.

\section{Theoretical Context}




\section{Defining Rubrics}

A rubric provides a scoring scheme to help guide a user in judging products or activities (Moskal, 2000). For example, rubrics are widely used in education to help guide people's evaluation of a variety of constructs, including students' writing performances, the quality of research projects, and the quality of educational resources (Bresciani et al., 2009; Custard \& Sumner, 2005; Rezaei \& Lovorn, 2010). Among them, a number of rubrics have been developed to evaluate the quality of OER, as people increasingly need assistance in identifying high-quality resources available on the Internet (e.g., Custard \& Sumner, 2005; Haughey \& Muirhead, 2005; Porcello \& Hsi, 2013).

However, the use of rubrics does not always lead to improved evaluation (Rezaei \&Lovorn, 2010). Indeed, an important consideration is a rubric's validity and reliability (e.g. Bresciani, et al., 2009; Jonsson \& Svingby, 2007; Rezaei \& Lovorn, 2010). Validity is the extent to which a rubric measures what it is purported to measure, while reliability is the extent to which the results from a rubric are consistent over time and across different raters (Kimberlin \& Winterstein, 2008; Moskal \& Leydens, 2000). Further, utility is another measure of the quality of a rubric, and has been promoted by many researchers (e.g., Ross, 2006; Willner, 1997).

Researchers and developers have taken different approaches to improving the performance of rubrics, such as evaluating the validity and reliability of rubrics through empirical testing, and improving the utility of rubrics by providing user support (Colton et al., 1997; Moskal \& Leydens, 2000; Wolfe, Kao, \& Ranney, 1998). Thus, to better understand the performance of different rubrics for evaluating the quality of OER, a review and synthesis of these rubrics along these different dimensions is needed.

\section{Characterizing Rubrics}

A rubric typically focuses on specific content, follows a particular development process, and targets at a particular application context (e.g., Arter \& Chappuis, 2006; Moskal, 2000; Moskal \& Leydens, 2000). Thus, we analyze OER quality rubrics following these three aspects.

The content aspect focuses on how the rubric deconstructs overall OER quality. In some rubrics, OER quality is defined in terms of multiple dimensions, where, in turn, each quality dimension can be comprised of one or more quality indicators. For example, the rubric from Pérez-Mateo, Maina, Guitert, and Romero (2011) first identifies three dimensions of OER quality - content, format, and process, and then proposes 42 indicators for these three dimensions. In contrast, other rubrics only identify quality indicators (e.g., the LORI). The content aspect also addresses whether rubrics have a ratings scale, and/ or provide a detailed scoring guide.

Second, the rubric development processes examines whether rubrics have reported empirical testing results, and whether they have been iteratively improved. Third, the application context aspect examines whether rubrics apply to a variety of OER, or are specific to a particular website or discipline, and whether the rubrics were designed for human or machine use. 


\section{Exploring Support for Rubric Users}

Simply creating a rubric is not sufficient. A rubric is also expected to be usable and to improve evaluation. The utility and effectiveness of a rubric depends on a variety of factors. For example, Colton et al. (1997) and Wolfe et al. (1998) noted that appropriate training about features of the rubric and strategies for using a rubric can improve its validity and reliability. Similarly, Rezaei and Lovorn (2010) argued that without appropriate user support, the use of rubrics may not necessarily improve the reliability or validity of assessment.

\section{Methods}

We conducted a search for rubrics designed to evaluate OER over a six-month period, ending in April 2014. In particular, we searched ERIC, Education Full Text, Library Literature and Information Sciences, and Google Scholar, using different combinations of the following descriptors: quality, open educational resources (OER), rubrics, evaluation, judgment, and assessment. We also identified articles by reviewing the reference lists of existing rubrics, and getting recommendations from other researchers. These different strategies led to more than 200 articles. However, as many resulting articles did not actually propose a rubric and some resulting rubrics were not designed for evaluating OER quality, we established the following inclusion criteria.

To qualify for inclusion in this review, each quality rubric had to meet four criteria: 1) it evaluated quality instead of relevance, or other features; 2) it focused on the OER instead of associated programs, services, or instruction; 3) it included a concrete rubric; 4) it provided an introduction or an explanation of the rubric; and 5) it was published later than 2000. Fourteen rubrics were ultimately included in our analysis.

The 14 rubrics were analyzed in two stages. The first stage examined rubrics in terms of the content, development process, application context framework. The second stage examined how rubrics provided user support.

\section{Findings}

\section{Rubric Characteristics}

The Appendix shows a summary of the 14 selected rubrics following the three aspects described above, and Table 1 shows frequencies of the various aspects in the selected rubrics. These results are explained in more detail below:

Table 1. Frequency of Different Aspects for Selected Rubrics

\begin{tabular}{llll}
\hline Aspect & Category & Frequency & Percent
\end{tabular}

\section{Content}




\begin{tabular}{llll}
\hline & $\begin{array}{l}\text { a. Rubrics identifying both quality } \\
\text { dimensions and quality indicators }\end{array}$ & 5 & $35.7 \%$ \\
& b. Rubrics identifying only quality indicators & 9 & \\
& & & $64.3 \%$ \\
\hline Rating Scale & a. Not specified & 5 & $35.7 \%$ \\
& b. Binary rating scale & 2 & $14.3 \%$ \\
& c. Four-point rating scale & 2 & $14.3 \%$ \\
d. Five-point rating scale & 5 & $35.7 \%$ \\
\hline Scoring Guide & a. Rubrics provide detailed scoring guide & 3 & $21.4 \%$ \\
& $\begin{array}{l}\text { b. Rubrics do not providedetailed scoring } \\
\text { guide }\end{array}$ & 11 & $78.6 \%$ \\
\hline
\end{tabular}

\section{Rubric Development Processes}

\begin{tabular}{lllc}
\hline & $\begin{array}{c}\text { a. Rubrics did not report empirical testing } \\
\text { results }\end{array}$ & 8 & $57.2 \%$ \\
Tested vs. Not Tested & b. Rubrics reported empirical testing results & 6 & \\
& & $62.8 \%$ \\
\hline \multirow{2}{*}{ Revised vs. Not Revised } & a. Rubrics revised several times & 3 & $21.4 \%$ \\
& b. Rubrics not revised & 11 & $78.6 \%$ \\
\hline
\end{tabular}

\section{Application Context}

\begin{tabular}{llll}
\hline & a. Generic rubrics & 7 & $50.0 \%$ \\
Generic vs. Specific & b. Rubrics specific to a website & 5 & $35.7 \%$ \\
& c. Rubrics specific to a discipline & 2 & $14.3 \%$ \\
\hline \multirow{2}{*}{ Automated vs. Manual } & a. Rubrics suited to automated evaluation & 2 & $14.3 \%$ \\
& b. Rubrics suited to manual evaluation & 12 & $85.7 \%$ \\
\hline
\end{tabular}


Content. First, while these rubrics all purport to measure OER quality, they emphasize different aspects of this construct. For example, the OER rubric from Achieve (2011) focuses on the pedagogical value of OER, the rubric from Kurilovas, Bireniene, and Serikoviene (2011) highlights the reusability of OER, while the EQuIP rubric from Achieve (2014) emphasizes OER alignment to educational standards.

Second, all rubrics choose to deconstruct the quality construct into many dimensions and/ or indicators. Specifically, as shown in Table 1, about one third of the rubrics (36\%) deconstruct quality into dimensions (each, in turn, comprised of one or more quality indicators), thereby reflecting a more nuanced notion of quality, while the majority (64\%) use only quality indicators. Moreover, while all rubrics are comprised of a series of quality indicators, the number of indicators in each rubric shows a wide spread (Mean $=15.53$, $\mathrm{Med}=15.00 ; \mathrm{SD}=10.72 ; \mathrm{Min}=3 ; \mathrm{Max}=42$ ). Figure 1 depicts the number of quality indicators across these rubrics. Note that the EQuIP rubric proposes different numbers of quality indicators for different disciplines (see Appendix), and an average is reported in Figure 1. It is also important to note that while a larger number of indicators can provide a more comprehensive evaluation, it comes with an associated burden on users in terms of applying each indicator in the rubric (Haughey \& Muirhead, 2005).

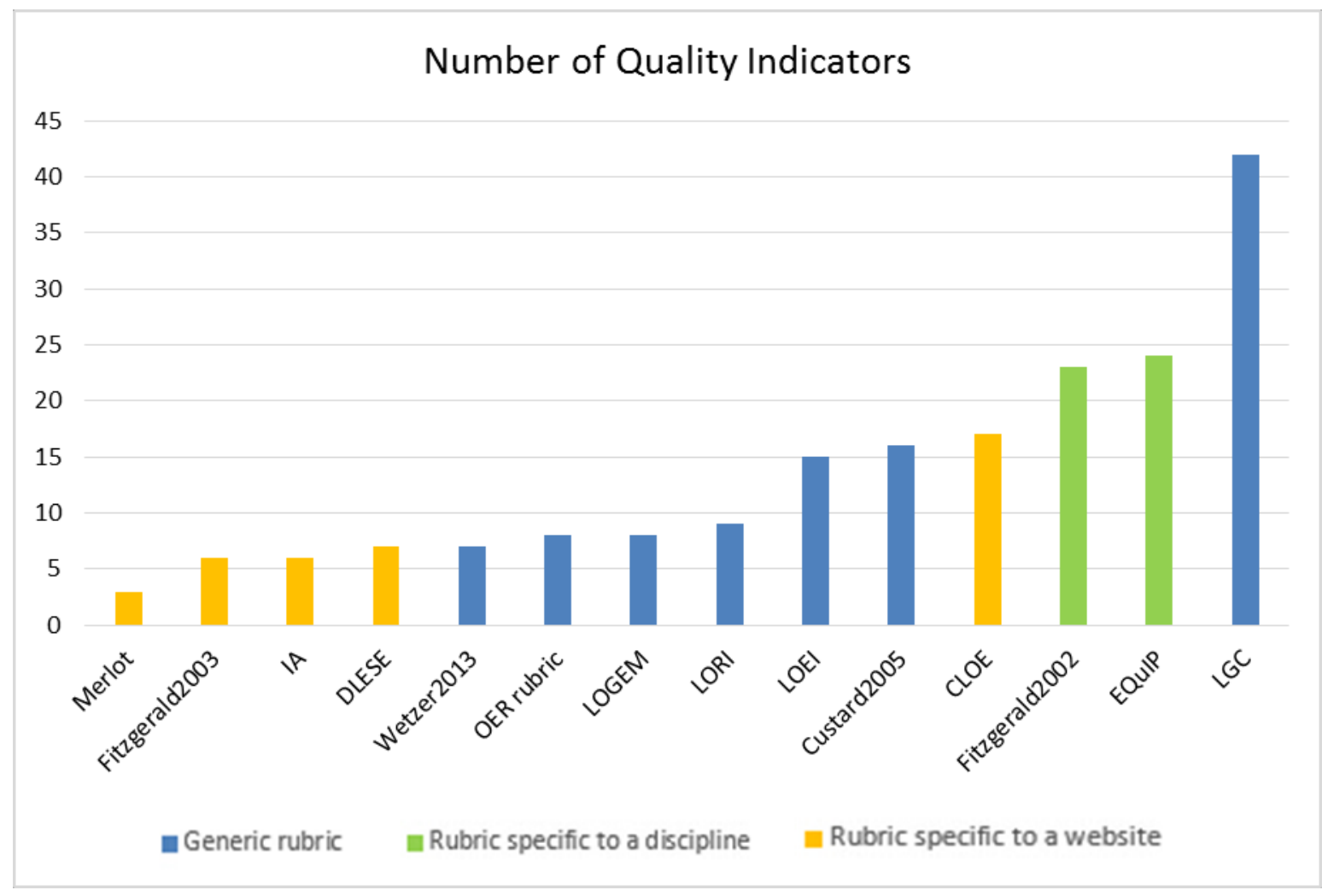

Figure 1. Number of quality indicators across rubrics, characterized by whether it's a generic or a specific rubric

Third, these rubrics share some common indicators. For example, many rubrics include "content quality" as a dimension for evaluating OER. Several rubrics elaborate this construct into indicators such as 
completeness, clarity, and accuracy (Fitzgerald et al., 2003; Nesbit et al., 2007; Leary, Giersch, Walker, \& Recker, 2009). In contrast, some rubrics also contain unique indicators. For example, the rubric from Haughey and Muirhead (2005) uniquely includes "value" as an important quality indicator of OER, emphasizing that OER should be appropriate for students with diverse needs, languages, and cultures. In addition, the rubric from Wetzler et al. (2013) is the only rubric that considers "sponsor" of OER as an important factor comprising OER quality.

Fourth, the use of rating scales in these rubrics differs. Among the 14 rubrics, five do not specify a rating scale at all. For the remaining nine rubrics, two adopt a binary (yes - no) rating scale. The other seven rubrics adopt a four-point or five-point rating scale, which may provide users with more discriminating power when rating OER.

Fifth, only the OER rubric from Achieve (2011), the EQuIP rubric from Achieve (2014), and the LORI from Nesbit et al. (2007) provide detailed scoring guides. These scoring guides list the steps to carry out the assessment, identify different requirements for different points on the scale, and/ or provide examples in order to help users provide more accurate ratings. Note that the provision of rating scales and scoring guides can facilitate users' application of these rubrics and thereby improve the performance (e.g., validity, reliability) of these rubrics (Barkaoui, 2010; Yuan, Recker, \&Diekema, , 2015).

Rubric development process. The rubrics were all developed through reviewing existing materials and prior studies, and thus not designed in a void. For example, Vargo, Nesbit, Belfer, and Archambault (2003) design and propose the LORI by reviewing work aimed at evaluating the quality of textbooks, courses, and instructional programs. However, among the 14 rubrics, only six have reported empirical results regarding their validity, reliability, or utility. Such studies can help increase the credibility of these rubrics as well as provide data for iterative improvement of the rubrics.

Finally, three rubrics - the OER rubric from Achieve (2011), the LORI from Nesbit et al. (2007), and the EQuIP rubric from Achieve (2014) - have been revised several times, while the remaining have not.

Application context. The 14 rubrics can be categorized in terms of their application contexts. As shown in Figure 1, seven rubrics (e.g., the OER rubric from Achieve (2011)) are very generic, and thus can be used to evaluate a variety of OER across different resource types and different subject domains. Another five rubrics are specific to particular websites (e.g., the rubric from Leary et al. (2009) applies to the Instructional Architect website). Two rubrics are specific to particular subject domains. In particular, the rubric from Fitzgerald and Byers (2002) is specific to the science domain, while the EQuIP rubric from Achieve (2014) is specific to math, literacy, and science.

Another important consideration is the target user: human or machine. Two rubrics - the rubrics from Custard and Sumner (2005) and Wetzler et al. (2013) - are aimed toward automated evaluation of OER quality. The remaining 12 rubrics are designed for use by people. 
In summary, despite of some commonalities, these rubrics show a wide diversity in terms of their content, development processes, and application contexts, which give users many choices. However, a lack of rating scales, scoring guides, empirical testing, and iterative revisions for many rubrics calls into question issues surrounding rubric reliability, validity, and utility.

\section{Rubric Support for Users}

Our analysis revealed that the rubrics provide a variety of support structures for users. First, many rubrics make themselves easily accessible. For example, after its release at no cost, the LORI was cited by many educational organizations, and consequently used by more teachers (Akpinar, 2008; Nesbit \& Li, 2004). Further, the LORI was referred to and studied by many researchers, which in turn lead to suggestions for revisions of this rubric, as well as a series of new rubrics (Haughey \& Muirhead, 2005).

Second, many rubric developers solicited user input. For example, the rubric from Pérez-Mateo et al. (2011) asked potential rubric users to suggest a set of indicators that can be used to evaluate OER quality. In particular, based on 114 participants' responses to an online survey, and validated with existing literature, Pérez-Mateo et al. (2011) identified 42 quality indicators, including indicators such as adequacy, consistency, and effectiveness. As another example, the EQuIP rubric from Achieve (2014) asked teachers to submit teaching resources, and a review panel reviewed and provided feedback using their rubric.

Third, some rubrics provide training materials. The Achieve organization provides training materials in PDF, PowerPoint, and video format for both the OER and the EQuIP rubrics. For example, the training materials associated with the OER rubric include a detailed handbook, which introduces the rubric, lists the steps for using the rubric, and provides links to examples. Additionally, rubric developers provide videos explaining the rating scale and showing how to apply rubrics in authentic situations.

Fourth, some rubric developers received support from government and other educational organizations. The Achieve organization, for example, collaborated with several U.S. states (e.g., California, Illinois). In particular, the Achieve organization introduced the basic concepts of OER to different states, developed recommendations for states on the use of rubrics for evaluating OER, helped them develop relevant strategies, and assisted them in implementing these strategies. In this way, the Achieve increased the awareness of OER in these states, which made the use of its rubrics very popular. Finally, developers of the Kurilovas et al. (2011) rubric worked with several European educational organizations, which made their rubric more popular in Europe.

\section{Conclusion}

This article first reviewed existing quality rubrics in terms of their content, development processes, and application contexts. For content, even though these rubrics were all comprised of a set of quality indicators and shared similar indicators, different rubrics had different emphases and some contained unique indicators. Over 35\% of the reviewed rubrics did not provide a rating scale, and only a small 
proportion offered detailed scoring guides. In terms of development processes, over $50 \%$ of the reviewed rubrics had not reported results from empirical testing, and only a small proportion of the rubrics had been revised several times. Lastly, the application contexts of rubrics differed in that some rubrics were more generic than others, and some rubrics were designed to support automated evaluation.

Thus, the research revealed a complex picture. On the positive side, rubrics showed great heterogeneity in the three aspects, providing users with multiple options and for diverse educational applications. On the negative side, only some rubrics provided rating scales, scoring guides, or empirical testing results. As shown in previous studies, the use of rating scales and scoring guides can improve users' evaluation reliability, and empirical testing and the iterative revision of rubrics allowed rubric developers to increasingly improve rubrics' validity, reliability, and usability (Akpinar, 2008; Barkaoui, 2010; Moskal \& Leydens, 2000; Vargo et al., 2003). Thus, the absence of rating scales, scoring guides, empirical testing, and iterative revisions in many rubrics raises concerns about their overall utility.

Additionally, this article reviewed the kinds of user support provided by these rubrics, and revealed that these supports came in various forms, such as providing training materials and soliciting user input. These supports were intended to increase the application scope and educational value of these rubrics, and thus are recommended as an important component of future rubric development.

The significance of this research lay in the following aspects. First, it revealed the current state of existing rubrics for evaluating OER quality, showed the characteristics of these rubrics, and identified what supporting structures were provided to users. Thus, it provided a basis for future research on rubrics.

Second, this review indicated that the quality and educational utility of OER depended not only on the content quality (e.g., accuracy, clarity) of resources, but also on the pedagogical values contained in these OER. In particular, these rubrics highlighted some pedagogical guidelines, such as aligning with standards, identifying appropriate learners, and showing the potential to engage learners. Thus, when using these rubrics to choose appropriate OER, users need to consider these pedagogical guidelines.

Third, the findings could help users in selecting appropriate rubrics for OER evaluation tasks. In particular, users can choose rubrics whose content, development processes, and application contexts align most with the purpose of their evaluation. For example, users may consider whether they intend to evaluate resources for a particular discipline or for multiple disciplines, whether they wish to focus more on the reusability of resources or on the alignment of resources with educational standards, whether they need detailed scoring guides or more freedom to make choices, and whether they need training and/or support from rubric developers.

Fourth, this research could facilitate the future development of rubrics by clarifying what is common and what is lacking in existing rubrics. For example, rubric developers should consider testing and iteratively revising their rubrics as well as provide a rating scale, scoring guide, and other training material. 
Finally, this research contributed to the improvement of OER quality. In particular, our research distilled common indicators for evaluating quality in OER, and helped illustrate what dimensions/aspects of quality have not been met by a certain resource, thereby providing suggestions on how to improve the OER.

\section{Acknowledgements}

Portions of this research were previously presented at the American Educational Research Association Annual Meeting (AERA 2015) in Chicago.

\section{References}

Abramovich, S., Schunn, C. D., \& Correnti, R. J . (2013). The role of evaluative metadata in an online teacher resource exchange. Educational Technology Research and Development, 61(6), 863-883.

Achieve, A. (2011). Rubrics for evaluating open education resource(OER) objects. Washington, D.C.: Achieve, Inc. Retrieved J anuary 9, 2013, http:// www.achieve.org/ achieve-oer-rubrics

Achieve, A. (2014). Educators evaluating quality instructional products. Retrieved April 9, 2014, http:// www.achieve.org/ EQuIP

Arter, J ., \& Chappuis, J . (2006). Creating \& recognizing quality rubrics. Pearson, Columbus.

Akpinar, Y. (2008). Validation of a learning object review instrument: Relationship between ratings of learning objects and actual learning outcomes. Interdisciplinary J ournal of Knowledge \& Learning Objects, 4, 291-302.

Atkins, D. E., Brown, J . S., \& Hammond, A. L. (2007). A review of the open educational resources (OER) movement: Achievements, challenges, and new opportunities. Retrieved J anuary 9,2013, http:// www.hewlett.org/ Programs/ Education/ OER/ OpenContent/ Hewlett+OER+Report.htm

Barkaoui, K. (2010). Variability in ESL essay rating processes: The role of the rating scale and rater experience. Language Assessment Quarterly, 7(1), 54-74.

Bethard, S., Wetzer, P., Butcher, K., Martin, J . H., \& Sumner, T. (2009, J une). Automatically characterizing resource quality for educational digital libraries. In Proceedings of the 9 th ACM/IEEE-CSjoint conference on Digital libraries (pp. 221-230). ACM.

Borgman, C. L., Abelson, H., Dirks, L., J ohnson, R., Koedinger, K. R., Linn, M. C., Lynch, C. A., Oblinger, D. G., Pea, R. D., Salen, K., Smith, M. S., Szalay, A. (2008). Fosteringlearning in the networked world: The cyberlearning opportunity and challenge, a 21st century agenda for the National Science Foundation. Report of the NSF Task Force on Cyberlearning. Virginia, US: NSF. 
Bresciani, M. J ., Oakleaf, M., Kolkhorst, F., Nebeker, C., Barlow, J ., Duncan, K., \& Hickmott, J . (2009). Examining design and inter-rater reliability of a rubric measuring research quality across multiple disciplines. Practical Assessment, Research \& Evaluation, 14(12), 1-7.

Bundsgaard, J ., \& Hansen, T. I. (2011). Evaluation of learning materials: A holistic framework. J ournal of Learning Design, 4(4).

Colton, D. A., Gao, X., Harris, D. J ., Kolen, M. J ., Martinovich-Barhite, D., Wang, T., \&Welch, C.J . (1997). Reliability issues with performanceassessments: A collection of papers. ACT Research Report Series, 97-3.

Custard, M., \& Sumner, T. (2005).Using machinelearning to support quality judgments. D-Lib Magazine, 11 (10). Retrieved from http:// www.dlib.org/ dlib/ october05/ custard/ 10custard.html

DLESE (2004). DLESE Reviewed Collection (DRC) best practices. Retrieved 2014 from http:// www.dlese.org/ Metadata/ collections/ drc-best-practices.php

Fitzgerald, M. A., \& Byers, A. (2002). A rubric for selecting inquiry-based activities. Science Scope, 26(1), 22-25.

Fitzgerald, M., Lovin, V., \& Branch, R. M. (2003). The gateway to educational materials: An evaluation of an online resource for teachers and an exploration of user behavior.J ournal of Technology and Teacher Education, 11(1), 21- 51.

Haughey, M., \& Muirhead, B. (2005).Evaluatinglearning objects for schools. E-J ournal of Instructional Sciences and Technology, 8(1). Retrieved from http://ascilite.org.au/ajet/ejist/docs/vol8_no1/fullpapers/eval_learnobjects_school.htm

J onsson, A., \& Svingby, G. (2007). The use of scoring rubrics: Reliability, validity and educational consequences. Educational Research Review, 2(2), 130-144.

Kastens, K. A., \& Butler, J .C. (2001). How to identify the "best" resources for the reviewed collection of the Digital Library for Earth System Education. Computers and theGeosciences, 27 (3), 375-378.

Kastens, K., Devaul, H., Ginger, K., Mogk, D., Defelice, B., DiLenonardo, C., Tahirkheli, S. (2005). Questions and challenges arising in building the collection of a digital library for education. D-Lib Magazine, 11(11). Retrieved from http:// mirror.dlib.org/dlib/ november05/kastens/11kastens.html

Kay, R., \& Knaack, L. (2007). Evaluating the use of learning objects for secondary school science. J ournal of Computers in Mathematics and Science Teaching, 26(4), 261-289. 
Khanna, P., \& Basak, P. C. (2013). An OER architecture framework: Needs and design. International Review of Research in Open \& Distance Learning, 14(1).

Kimberlin, C. L., \&Winterstein, A. G. (2008). Validity and reliability of measurement instruments used in research. American J ournal of Health-System Pharmacy, 65(23).

Kurilovas, E., Bireniene, V., \& Serikoviene, S. (2011). Methodology for evaluating quality and reusability of learning Objects. Electronic J ournal of e-Learning, 9(1).

Leacock, T. L., \&Nesbit, J . C. (2007). A framework for evaluating the quality of multimedia learning resources. Educational Technology \& Society, 10(2), 44-59.

Leary, H., Giersch, S., Walker, A., \& Recker, M. (2009). Developing a review rubric for learning resources in digital libraries. In Proceedings of the 9th ACM/ IEEE-CS joint conference on Digital libraries (pp. 421-422). ACM.

Leary, H., Giersch, S., Walker, A., \& Recker, M. (2011). Developing and Using a Guide to Assess Learning Resource Quality in Educational Digital Libraries. In Kuo Hung Huang (Ed.), Digital Libraries Methods and Applications (pp. 181-196). InTech (ISBN: 978-953-307-203-6, Available from:http:// www.intechopen.com/ articles/ show/ title/ developing-and-using-a-guide-to-assesslearning-resource-quality-in-educational-digital-libraries)

Merlot (2014). MERLOT peer review process. Retrieved April 9, 2014, http://info.merlot.org/ merlothelp/index.htm\#about_merlot.htm

Moskal, Barbara M. (2000). Scoring rubrics: what, when and how? Practical Assessment, Research \& Evaluation, 7(3). Retrieved May 6, 2014 from http:// PAREonline.net/ getvn.asp?v=7\&n=3

Moskal, B. M., \& Leydens, J . A. (2000). Scoring rubric development: Validity and reliability. Practical Assessment, Research \& Evaluation, 7(10), 71-81.

Nesbit, J ., Belfer, K., \& Leacock, T. (2007). Learning object reviewinstrument (LORI), Version 1.5. ELearning Research and Assessment (eLera) and the Portal for Online Objects in Learning (POOL).

Nesbit, J . C., \& Li, J . (2004). Web-based tools for learning object evaluation. Proceedings of the International Conference on Education and Information Systems: Technologies and Applications, 2, 334-339.

Pérez-Mateo, M., Maina, M. F., Guitert, M., \& Romero, M. (2011). Learner generated content: Quality criteria in online collaborative learning. European J ournal of Open, Distanceand E-Learning. http:// www.eurodl.org/ materials/special/2011/Perez-Mateo et al.htm 
Porcello, D., \&Hsi, S. (2013). Crowdsourcingand Curating Online Education Resources. Science, 341(6143), 240-241. http:// www.sciencemag.org/content/341/6143/240.full

Rezaei, A. R., \& Lovorn, M. (2010). Reliability and validity of rubrics for assessment through writing. Assessing writing, 15(1), 18-39.

Rodríguez, J . S., Dodero, J . M., \&Alonso, S. S. (2011). Ascertainingthe relevance of open educational resources by integrating various quality indicators. RUSC: Revista de Universidad y Sociedad del Conocimiento, 8(2).

Ross, J . A. (2006). The reliability, validity, and utility of self-assessment. Practical Assessment Research \& Evaluation, 11(10).

U.S. Department of Education, Office of Educational Technology (2010). Transforming American Education: Learning Powered by Technology. Washington, D.C.

Vargo, J ., Nesbit, J . C., Belfer, K., \&Archambault, A. (2003). Learning object evaluation: Computermediated collaboration and inter-rater reliability. International J ournal of Computers and Applications, 25(3), 198-205.

Wetzler, P., Bethard, S., Leary, H., Butcher, K., Zhao, D., Martin, J . S., \& Sumner, T. (2013).Characterizing and predicting the multi-faceted nature of quality in educational web resources. Transactions on InteractiveIntelligent Systems, 3(3), 15:1-25.

Willner, P. (1997). Validity, reliability and utility of the chronic mild stress model of depression: a 10-year review and evaluation. Psychopharmacology, 134(4), 319-329.

Wolfe, E. W., Kao, C., \& Ranney, M. (1998). Cognitive differences in proficient and nonproficient essay scorers. Written Communication, 15(4).

Yuan, M., Recker, M. \& Diekema, A. (2015). Do Rubrics Help? An Exploratory Study of Teachers' Perception and Use of Rubrics for Evaluating Open Educational Resource Quality. In Proceedings of the 2015 Society for Information Technology \& Teacher Education International Conference (pp. 1314-1321). Las Vegas, NV: Association for the Advancement of Computing in Education (AACE). 


\section{Appendix}

An Overview of Selected Rubrics

\begin{tabular}{|c|c|c|c|c|c|}
\hline \multirow[b]{2}{*}{ Rubric } & \multicolumn{3}{|l|}{ Content } & \multirow[b]{2}{*}{$\begin{array}{l}\text { Rubric } \\
\text { Development } \\
\text { Processes }\end{array}$} & \multirow[b]{2}{*}{$\begin{array}{l}\text { Application } \\
\text { Context }\end{array}$} \\
\hline & $\begin{array}{l}\text { Quality } \\
\text { Dimensions / } \\
\text { Indicators }\end{array}$ & $\begin{array}{l}\text { Rating } \\
\text { Scale }\end{array}$ & $\begin{array}{l}\text { Scoring } \\
\text { Guide }\end{array}$ & & \\
\hline $\begin{array}{l}\text { Rubric to } \\
\text { evaluate OER } \\
\text { objects (OER } \\
\text { rubric; Achieve, } \\
\text { 2011) }\end{array}$ & $\begin{array}{l}\text { 8 quality } \\
\text { indicators: } \\
\text { - Degree of alignmı nt } \\
\text { to standards } \\
\text { - Quality of } \\
\text { explanation of the } \\
\text { subject matter } \\
\text { - Utility of materials } \\
\text { designed to support } \\
\text { teaching } \\
\text { - Quality of } \\
\text { assessment } \\
\text { - Quality of } \\
\text { technological } \\
\text { interactivity } \\
\text { - Quality of } \\
\text { instructional and } \\
\text { practice exercise } \\
\text { - Opportunities for } \\
\text { deeper learning } \\
\text { - Assurance of } \\
\text { accessibility }\end{array}$ & $\begin{array}{l}0-3 \& \text { N/A } \\
\text { (3: } \\
\text { superior, 2: } \\
\text { strong, 1: } \\
\text { limited, 0: } \\
\text { very } \\
\text { weak/ none, } \\
\text { N/A: not } \\
\text { applicable) }\end{array}$ & $\begin{array}{l}\text { - Gives } \\
\text { detailed } \\
\text { scoring } \\
\text { guide for } \\
\text { all five } \\
\text { scores }\end{array}$ & $\begin{array}{l}\text { - Did not } \\
\text { report } \\
\text { empirical } \\
\text { testing } \\
\text { results } \\
\text { - Revised } \\
\text { several times }\end{array}$ & $\begin{array}{l}\text { - Evaluatea } \\
\text { variety of } \\
\text { OER across } \\
\text { different } \\
\text { content } \\
\text { areas and } \\
\text { types } \\
\text { - Apply to } \\
\text { the } \\
\text { smallest } \\
\text { meaningful } \\
\text { unit (e.g., a } \\
\text { single } \\
\text { lesson, a } \\
\text { complete } \\
\text { unit of } \\
\text { study) } \\
\text { - Generic } \\
\text { rubric }\end{array}$ \\
\hline
\end{tabular}




\begin{tabular}{|c|c|c|c|c|c|}
\hline $\begin{array}{l}\text { Learning Object } \\
\text { Evaluation } \\
\text { Instrument } \\
\text { (LOEI; Haughey } \\
\text { \& Muirhead, } \\
\text { 2005) }\end{array}$ & $\begin{array}{l}5 \text { quality } \\
\text { dimensions (15 } \\
\text { quality indicators): } \\
\text { - Integrity } \\
\text { - Usability } \\
\text { - Learning } \\
\text { - Design } \\
\text { - Value }\end{array}$ & $\begin{array}{l}\text { 0-4 (0: } \\
\text { absent, 1: } \\
\text { weak, 2: } \\
\text { moderate, } \\
\text { 3: strong, } \\
\text { 4: perfect) }\end{array}$ & $\begin{array}{l}\text { - No } \\
\text { scoring } \\
\text { guide } \\
\text { provided }\end{array}$ & $\begin{array}{l}\text { - Reported } \\
\text { empirical } \\
\text { testing } \\
\text { results }\end{array}$ & $\begin{array}{l}\text { - Examine } \\
\text { school-level } \\
\text { content in } \\
\text { K-12 } \\
\text { contexts } \\
\text { - More } \\
\text { generic } \\
\text { rubric }\end{array}$ \\
\hline $\begin{array}{l}\text { Learning Objects } \\
\text { Quality } \\
\text { Evaluation Model } \\
\text { (Kurilovas, } \\
\text { Bireniene, \& } \\
\text { Serikoviene, } \\
\text { 2011) }\end{array}$ & $\begin{array}{l}8 \text { quality } \\
\text { indicators: } \\
\text { - Technological } \\
\text { criteria } \\
\text { - Design and usability } \\
\text { - Working stability } \\
\text { - Architecture } \\
\text { - Interactivity level } \\
\text { - Language } \\
\text { independence } \\
\text { - Ease of use, } \\
\text { intuitiveness } \\
\text { - Open license, cost }\end{array}$ & $\begin{array}{l}\text { Bad, poor, } \\
\text { fair, good, } \\
\text { excellent }\end{array}$ & $\begin{array}{l}\text { - No } \\
\text { scoring } \\
\text { guide } \\
\text { provided }\end{array}$ & $\begin{array}{l}\text { - } \text { Reported } \\
\text { empirical } \\
\text { testing } \\
\text { results }\end{array}$ & $\begin{array}{l}\text { - Evaluate } \\
\text { the quality } \\
\text { of different } \\
\text { learning } \\
\text { objects } \\
\text { - Generic } \\
\text { rubric }\end{array}$ \\
\hline $\begin{array}{l}\text { Rubric to } \\
\text { evaluate Learner } \\
\text { Generated } \\
\text { Content (LGC; } \\
\text { Pérez-Mateo, } \\
\text { Maina, Guitert \& } \\
\text { Romero, 2011) }\end{array}$ & $\begin{array}{l}3 \text { quality } \\
\text { dimensions ( } 42 \\
\text { quality indicators): } \\
\text { - Content } \\
\text { - Format }\end{array}$ & $\begin{array}{l}\text { Not } \\
\text { specified }\end{array}$ & $\begin{array}{l}\text { - No } \\
\text { scoring } \\
\text { guide } \\
\text { provided }\end{array}$ & $\begin{array}{l}\text { - Did not } \\
\text { report } \\
\text { empirical } \\
\text { testing } \\
\text { results }\end{array}$ & $\begin{array}{l}\text { - Evaluate } \\
\text { the } \\
\text { resources } \\
\text { generated } \\
\text { by learners } \\
\text { - Generic }\end{array}$ \\
\hline
\end{tabular}




\begin{tabular}{|c|c|c|c|c|c|}
\hline & - Process & & & & rubric \\
\hline $\begin{array}{l}\text { Learning Object } \\
\text { Review } \\
\text { Instrument } \\
\text { (LORI, Leacock } \\
\text { \&Nesbit, 2007; } \\
\text { Nesbit, Belfer, \& } \\
\text { Leacock, 2007; } \\
\text { Vargo, Nesbit, } \\
\text { Belfer, \& } \\
\text { Archambault, } \\
\text { 2003) }\end{array}$ & $\begin{array}{l}9 \text { quality } \\
\text { indicators: } \\
\text { - Content quality } \\
\text { - Learning goal } \\
\text { alignment } \\
\text { - Feedback and } \\
\text { adaptation } \\
\text { - Motivation } \\
\text { - Presentation design } \\
\text { - Interaction usability } \\
\text { - Accessibility } \\
\text { - Reusability } \\
\text { - Standards } \\
\text { compliance }\end{array}$ & $\begin{array}{l}\text { 1-5\&N/A } \\
\text { (1: poor, 5: } \\
\text { excellent, } \\
\text { N/A: rubric } \\
\text { not } \\
\text { applicable) }\end{array}$ & $\begin{array}{l}\text { - Gives } \\
\text { detailed } \\
\text { scoring } \\
\text { guide for } \\
\text { point } 1 \\
\text { and 5, and } \\
\text { give } \\
\text { example } \\
\text { for point } 3\end{array}$ & $\begin{array}{l}\text { - Reported } \\
\text { empirical } \\
\text { testing } \\
\text { results } \\
\text { - Revised } \\
\text { several times }\end{array}$ & $\begin{array}{l}\text { - Evaluate } \\
\text { multimedia } \\
\text { learning } \\
\text { objects in } \\
\text { an } \\
\text { individual } \\
\text { or } \\
\text { collaborativ } \\
\text { e way } \\
\text { - Generic } \\
\text { rubric }\end{array}$ \\
\hline $\begin{array}{l}\text { Rubric from } \\
\text { Fitzgerald, Lovin, } \\
\text { \&Branch (2003) }\end{array}$ & $\begin{array}{l}6 \text { quality } \\
\text { indicators: } \\
\text { - Accuracy } \\
\text { - Appropriateness } \\
\text { - Clarity } \\
\text { - Completeness } \\
\text { - Motivation } \\
\text { - Organization }\end{array}$ & $\begin{array}{l}\text { Not } \\
\text { specified }\end{array}$ & $\begin{array}{l}\text { - No } \\
\text { scoring } \\
\text { guide } \\
\text { provided }\end{array}$ & $\begin{array}{l}\text { - Did not } \\
\text { report } \\
\text { empirical } \\
\text { testing } \\
\text { results }\end{array}$ & $\begin{array}{l}\text { - Review } \\
\text { materials } \\
\text { for } \\
\text { inclusion in } \\
\text { Gateway to } \\
\text { Educationa } \\
\text { l Materials } \\
\text { website } \\
\text { - Rubric } \\
\text { specific to a } \\
\text { website }\end{array}$ \\
\hline
\end{tabular}




\begin{tabular}{|c|c|c|c|c|c|}
\hline $\begin{array}{l}\text { Digital Library } \\
\text { for Earth System } \\
\text { Education } \\
\text { (DLESE) review } \\
\text { rubric (DLESE, } \\
\text { 2004; Kastens \& } \\
\text { Butler, 2001; } \\
\text { Kastens, 2005) }\end{array}$ & $\begin{array}{l}7 \text { quality } \\
\text { indicators: } \\
\text { - Scientific accuracy } \\
\text { - Importance or } \\
\text { significance } \\
\text { - Pedagogical } \\
\text { effectiveness } \\
\text { - Well-documented } \\
\text { - Ease of use for } \\
\text { students and faculty } \\
\text { - Power to inspire or } \\
\text { motivate students } \\
\text { - Robustness as a } \\
\text { digital resource }\end{array}$ & $\begin{array}{l}\text { Not } \\
\text { specified }\end{array}$ & $\begin{array}{l}\text { - No } \\
\text { scoring } \\
\text { guide } \\
\text { provided }\end{array}$ & 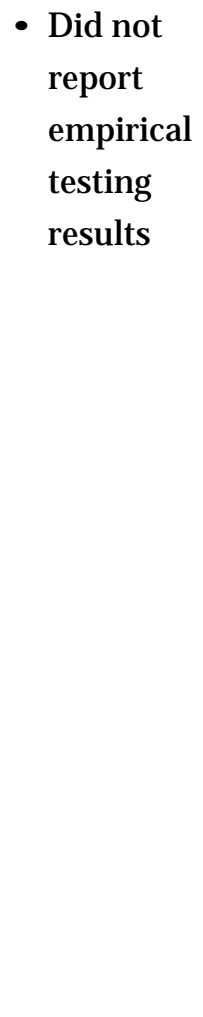 & $\begin{array}{l}\text { - Review } \\
\text { resources } \\
\text { for } \\
\text { inclusion in } \\
\text { DLESE } \\
\text { - Rubric } \\
\text { specific to a } \\
\text { website }\end{array}$ \\
\hline $\begin{array}{l}\text { Rubric from } \\
\text { Merlot } \\
\text { (www.merlot.org; } \\
\text { Haughey \& } \\
\text { Muirhead, 2005) }\end{array}$ & $\begin{array}{l}\text { 3 quality } \\
\text { indicators: } \\
\text { - Quality of content } \\
\text { - Potential } \\
\text { effectiveness as a } \\
\text { teaching-learning } \\
\text { tool } \\
\text { - Ease of use }\end{array}$ & $\begin{array}{l}\text { 1-5 (1: } \\
\text { material } \\
\text { not worthy } \\
\text { of use, } \\
\text { 5:excellent } \\
\text { all around) }\end{array}$ & $\begin{array}{l}\text { - No } \\
\text { scoring } \\
\text { guide } \\
\text { provided }\end{array}$ & $\begin{array}{l}\text { - Did not } \\
\text { report } \\
\text { empirical } \\
\text { testing } \\
\text { results }\end{array}$ & $\begin{array}{l}\text { - Review } \\
\text { learning } \\
\text { objects for } \\
\text { inclusion in } \\
\text { website } \\
\text { - Apply in } \\
\text { both } \\
\text { individual } \\
\text { and } \\
\text { collaborativ } \\
\text { e way } \\
\text { - Rubric } \\
\text { specific to a } \\
\text { website }\end{array}$ \\
\hline
\end{tabular}




\begin{tabular}{|c|c|c|c|c|c|}
\hline $\begin{array}{l}\text { Collaborative } \\
\text { Learning Object } \\
\text { Exchange } \\
\text { (CLOE; Haughey } \\
\text { \& Muirhead, } \\
\text { 2005) }\end{array}$ & $\begin{array}{l}\text { 17 quality } \\
\text { indicators: } \\
\text { - The content of the } \\
\text { learning object is } \\
\text { accurate. } \\
\text { - The use of } \\
\text { technology is } \\
\text { appropriate for this } \\
\text { content. } \\
\text { - The content is } \\
\text { presented clearly } \\
\text { and professionally } \\
\text { (spelling/ grammar, } \\
\text { et cetera). } \\
\text { - Appropriate } \\
\text { academic references } \\
\text { are provided. } \\
\text { - Thereare clear } \\
\text { instructions for } \\
\text { using the learning } \\
\text { are provided. } \\
\text { - There are clear } \\
\text { learning objectives. } \\
\text { - Thelearning object } \\
\text { meets the stated } \\
\text { learning objectives. } \\
\text { ability/ demographic } \\
\text { are clearly identified } \\
\text { (academic level } \\
\text { addressed/ technical } \\
\text { - }\end{array}$ & $\begin{array}{l}\text { Not } \\
\text { specified }\end{array}$ & $\begin{array}{l}\text { - No } \\
\text { scoring } \\
\text { guide } \\
\text { provided }\end{array}$ & $\begin{array}{l}\text { - Did not } \\
\text { report } \\
\text { empirical } \\
\text { testing } \\
\text { results }\end{array}$ & $\begin{array}{l}\text { - Peer review } \\
\text { of materials } \\
\text { for } \\
\text { inclusion in } \\
\text { the website } \\
\text { - Include } \\
\text { two review } \\
\text { panels: } \\
\text { instruction } \\
\text { al } \\
\text { designers, } \\
\text { subject } \\
\text { matter } \\
\text { experts } \\
\text { - Rubric } \\
\text { specific to a } \\
\text { website }\end{array}$ \\
\hline
\end{tabular}


object.

- The technology helps learners to engage effectively with the concept/ skill/idea.

- The learning object provides an opportunity for learners to obtain feedback within or outside the learning object.

- The author provides evidence that the learning object enhances student learning.

- Pre-requisite knowledge/ skills, if needed, are identified.

- The learning object stands alone and could be used in other learning environments.

- The learning object is easy to use (i.e. navigation, user control).

- The author indicates whether the learning object is accessible for learners with 
diverse needs.

- Technical

requirements for the

learning object are

provided. (Draft

Review Guidelines

2003)

\begin{tabular}{|c|c|c|c|c|c|}
\hline $\begin{array}{l}\text { Rubric to } \\
\text { evaluate learning } \\
\text { resources in } \\
\text { digital libraries } \\
\text { (Leary, Giersch, } \\
\text { Walker, \& } \\
\text { Recker, , 2009; } \\
\text { Leary, Giersch, } \\
\text { Walker, \& } \\
\text { Recker, 2011) }\end{array}$ & $\begin{array}{l}6 \text { quality } \\
\text { indicators: } \\
\text { - Content accuracy } \\
\text { - Text clarity } \\
\text { - Links in project } \\
\text { - Project } \\
\text { completeness, } \\
\text { includes the state } \\
\text { standard learning } \\
\text { goal, assessment, } \\
\text { etc. } \\
\text { - Purpose of the } \\
\text { project } \\
\text { - Overall rating of the } \\
\text { project }\end{array}$ & $\begin{array}{l}\text { 1-5 (1:low } \\
\text { quality, } \\
\text { 5:high } \\
\text { quality) }\end{array}$ & $\begin{array}{l}\text { - No } \\
\text { scoring } \\
\text { guide } \\
\text { provided }\end{array}$ & $\begin{array}{l}\text { - } \text { Reported } \\
\text { empirical } \\
\text { testing } \\
\text { results }\end{array}$ & $\begin{array}{l}\text { - Rubric } \\
\text { specific to } \\
\text { the } \\
\text { Instruction } \\
\text { al Architect } \\
\text { website }\end{array}$ \\
\hline $\begin{array}{l}\text { Rubric to } \\
\text { evaluate } \\
\text { instructional } \\
\text { materials } \\
\text { (Fitzgerald \& } \\
\text { Byers, 2002) }\end{array}$ & $\begin{array}{l}4 \text { quality } \\
\text { dimensions (23 } \\
\text { quality indicators): } \\
\text { - Increase students' } \\
\text { understanding of the } \\
\text { science subject } \\
\text { matter investigated } \\
\text { - Gain an } \\
\text { understanding of } \\
\text { how scientists study }\end{array}$ & $\begin{array}{l}\text { Not } \\
\text { specified }\end{array}$ & $\begin{array}{l}\text { - No } \\
\text { scoring } \\
\text { guide } \\
\text { provided }\end{array}$ & $\begin{array}{l}\text { - Did not } \\
\text { report } \\
\text { empirical } \\
\text { testing } \\
\text { results }\end{array}$ & $\begin{array}{l}\text { - Review } \\
\text { resources } \\
\text { to support } \\
\text { inquiry in } \\
\text { the } \\
\text { classroom } \\
\text { - Rubric } \\
\text { specific to } \\
\text { science } \\
\text { domain }\end{array}$ \\
\hline
\end{tabular}


the natural world

- Develop the ability

to conduct

investigation

- Develop the habits of

mind associated with

science

\begin{tabular}{|c|c|c|c|c|c|}
\hline $\begin{array}{l}\text { Educators } \\
\text { Evaluating the } \\
\text { Quality of } \\
\text { Instructional } \\
\text { Products (EQuIP; } \\
\text { Achieve, 2014) }\end{array}$ & $\begin{array}{l}4 \text { quality } \\
\text { dimensions for } \\
\text { math and literacy } \\
\text { (31 quality } \\
\text { indicators for K-- } 2 \\
\text { literacy, } 29 \\
\text { indicators for K3-- } \\
\mathbf{5} \text { literacy, and } 19 \\
\text { indicators for } \\
\text { math): } \\
\text { - Alignment to the } \\
\text { depth of the } \\
\text { Common Core State } \\
\text { Standards (CCSS) } \\
\text { - Key shifts in the } \\
\text { CCSS } \\
\text { - Instructional } \\
\text { supports } \\
\text { - Assessment } \\
\text { 3 quality } \\
\text { dimensions for } \\
\text { science ( } 18 \text { quality } \\
\text { indicators) } \\
\text { - Alignment to the } \\
\text { Next Generation } \\
\text { Science Standards } \\
\end{array}$ & $0-3$ & $\begin{array}{l}\text { - Gives } \\
\text { detailed } \\
\text { scoring } \\
\text { guide }\end{array}$ & 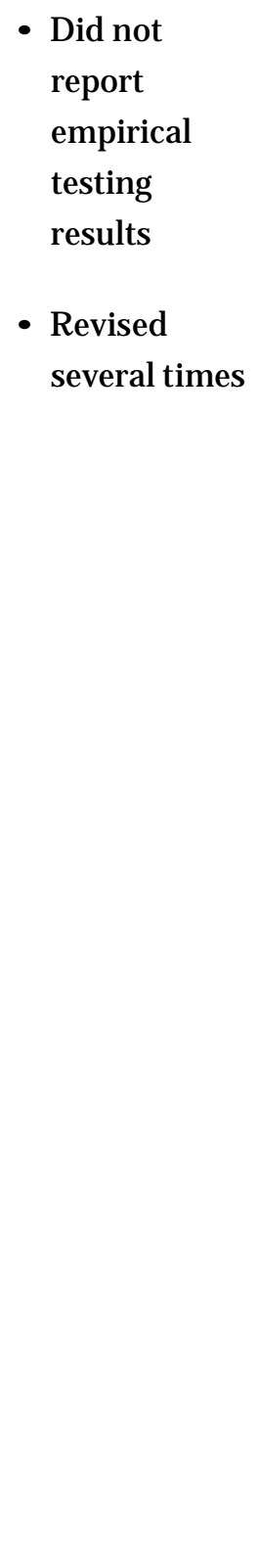 & $\begin{array}{l}\text { - Evaluate } \\
\text { instruction } \\
\text { al materials } \\
\text { for use in } \\
\text { schools } \\
\text { - Rubric } \\
\text { specific to } \\
\text { mathemati } \\
\text { cs, literacy, } \\
\text { and science } \\
\text { domains }\end{array}$ \\
\hline
\end{tabular}


(NGSS)

- Instructional supports

- Monitoring Student

Progress

\begin{tabular}{|c|c|c|c|c|c|}
\hline $\begin{array}{l}\text { Rubric from } \\
\text { Custard \& } \\
\text { Sumner (2005) }\end{array}$ & $\begin{array}{l}5 \text { quality } \\
\text { dimensions (16 } \\
\text { quality indicators): } \\
\text { - Provenance } \\
\text { - Description } \\
\text { - Content } \\
\text { - Social authority } \\
\text { - Availability }\end{array}$ & $\begin{array}{l}\mathrm{Y} / \mathrm{N} \text { and } \\
\text { text entry }\end{array}$ & $\begin{array}{l}\text { - No } \\
\text { scoring } \\
\text { guide } \\
\text { provided }\end{array}$ & $\begin{array}{l}\text { - Reported } \\
\text { empirical } \\
\text { testing } \\
\text { results }\end{array}$ & $\begin{array}{l}\text { - Evaluate } \\
\text { resources } \\
\text { in an } \\
\text { automated } \\
\text { way } \\
\text { - Generic } \\
\text { rubric }\end{array}$ \\
\hline $\begin{array}{l}\text { Rubric from } \\
\text { Bethard, Wetzer, } \\
\text { Butcher, Martin, } \\
\text { \&Sumner } \\
\text { (2009); Wetzler } \\
\text { et al. (2013)- }\end{array}$ & $\begin{array}{l}\text { 7 quality indicators } \\
\text { - Has prestigious } \\
\text { sponsor } \\
\text { - Content is } \\
\text { appropriatefor age } \\
\text { range } \\
\text { - Has sponsor } \\
\text { - Identifies learning } \\
\text { goals } \\
\text { - Has instructions } \\
\text { - Identifies age range } \\
\text { - Organized for }\end{array}$ & $\mathrm{Y} / \mathrm{N}$ & $\begin{array}{l}\text { - No } \\
\text { scoring } \\
\text { guide } \\
\text { provided }\end{array}$ & $\begin{array}{l}\text { - Reported } \\
\text { empirical } \\
\text { testing } \\
\text { results }\end{array}$ & $\begin{array}{l}\text { - Evaluate } \\
\text { resources } \\
\text { in an } \\
\text { automated } \\
\text { way } \\
\text { - Generic } \\
\text { rubric }\end{array}$ \\
\hline
\end{tabular}


learning goals

Note. If a rubric proposes both quality dimensions and quality indicators, then the quality dimensions are presented here. If a rubric only proposes quality indicators, then the quality indicators are presented. If a rubric was revised several times, then the quality indicators and rating scales were reported based on the latest version of the rubric.

(C) Yuan \& Recker

\section{Athabasca University $\mathbf{Z}$}

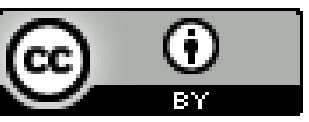

